\title{
Descartes on the Creation of the Eternal Truths
}

\author{
Danielle Macbeth \\ Department of Philosophy, \\ Haverford College \\ 370 Lancaster Avenue, \\ Haverford, PA 19041, USA \\ E-mail: dmacbeth@haverford.edu
}

\begin{abstract}
On 15 April 1630, in a letter to Mersenne, Descartes announced that on his view God creates the truths of mathematics. Descartes returned to the theme in subsequent letters and some of his Replies but nowhere is the view systematically developed and defended. It is not clear why Descartes came to espouse the creation doctrine, nor even what exactly it is. Some have argued that his motivation was theological, that God creates the eternal truths, including the truths of logic, because and insofar as God is omnipotent and the creator of all things. I develop and defend a different reading according to which Descartes was led to espouse the creation doctrine by a fundamental shift in his understanding of the correct mode of inquiry in metaphysics and mathematics: by 1630, the God-created truths came to play the role in inquiry that until then, in the Rules for the Direction of the Mind, had been played by images.
\end{abstract}

Key words: Descartes' creation doctrine, logical necessity, logical truth, mathematical truths, mathematical necessity, non-logical necessity

On 15 April 1630, Descartes wrote to Mersenne that "the mathematical truths which you call eternal have been laid down by God and depend on him entirely no less than the rest of his creatures" (CSMK III 23; AT I 145). ${ }^{1}$ This is the first

1 I use the following standard abbreviations: AT for Adam, C. \& Tannery, P., eds. (1964-1976), Oeuvres de Descartes, 12 vols., revised edition, Paris: Vrin/CNRS; CSM for Cottingham, J.; Stoothoff, R. \& Murdoch, D., eds. (1984-1985), The Philosophical Writings of Descartes, 2 vols., Cambridge: Cambridge University Press; and CSMK for Cottingham, J.; Stoothoff, R.; Murdoch, D. \& Kenny, A., eds. (1991), The Philosophical Writings of Descartes, vol. 3, Cambridge: Cambridge University Press. 
we hear of what has come to be called Descartes' creation doctrine. ${ }^{2}$ Descartes returns to the theme in subsequent letters to Mersenne, as well as in letters to More and Mesland, and in some of his Replies. Nowhere does he systematically develop and defend the view. ${ }^{3}$ We do not know why Descartes came to espouse the creation doctrine, nor even what exactly it is.

Descartes claims that the eternal truths are freely created by God, that God could have done otherwise. But if so, in what sense are those truths necessary? Some, for example, Frankfurt (1977) and Van Cleve (1994), have argued that if God could have done otherwise, as Descartes repeatedly claims, then the created truths cannot be necessary, despite Descartes' claims to the contrary. Others, including Geach (1973), Curley (1984), Osler (1985), and Kaufman (2002), hold-as Descartes himself seems to indicate in a letter to Mesland written on 2 May $1644^{4}$ - that the eternal truths that God creates are necessary but not necessarily necessary. But is it even coherent to claim that there are necessary truths that nonetheless depend for their truth on the free and indifferent will of the creator?

A second major interpretive challenge concerns the nature and ontological status of the eternal truths: when God created the eternal truths, what exactly was it that was created thereby? Kenny (1970), Wilson (1978), Schmaltz (1991), Bennett (1994), Nolan (1997), and Rozemond (2008) are among those addressing this question; six different answers are provided no one of which is clearly superior to the others.

A third issue concerns the scope of the creation doctrine. Although it is manifest that Descartes holds that the truths of mathematics and at least some metaphysical

2 The label is due to Wilson, 1978. As she points out, the doctrine appears to have two parts, first, that God creates the eternal truths (more exactly, the essences on the basis of which to determine what the eternal truths are), and second, that God implants in us ideas of these essences so that we may discover the eternal truths by reflection alone: "God has created our minds in such a way that we cannot directly conceive the opposite of things he has willed to be necessary or eternal" (Wilson, 1978, p. 127).

3 In that first letter to Mersenne, Descartes says that he will discuss the doctrine in his projected treatise on physics. Despite his intention, the doctrine is not so much as mentioned in any of Descartes' formally written works, perhaps because it turned out to be so very controversial. No one before Descartes had suggested such a thing, and as noted below, both Leibniz and Malebranche, among others, explicitly rejected it after it had been introduced by Descartes.

4 Descartes writes: "even if God has willed that some truths should be necessary, this does not mean that he willed them necessarily; for it is one thing to will that they be necessary, and quite another to will this necessarily, or to be necessitated to will it" (CSMK III 235; AT IV 118). Notice that Descartes does not here positively assert that this is how it is with the eternal truths. 
truths depend on God's free decree, does he think the same about the necessary truths about God, for example, that God exists, is omnipotent, and is not a deceiver?5 The truths of physics are also not obviously among the eternal truths that are within the scope of the creation doctrine; Broughton (1987) argues that, at least after the Meditations, Descartes held that they are not. And then there is the question of what is logically necessary: is what is true as a matter of pure logic, for example, that $a=a$, also freely created by God? Most-including Geach (1973), Frankfurt (1977), Wilson (1978), Alanen (1991), and Broughton (1987; 2002) —assume without question that Descartes does indeed intend that even the truths of logic are included within the scope of his creation doctrine. But there are dissenting voices, for instance, Funkelstein (1975).

And there is, finally, in addition to these questions about what the doctrine is, the question of Descartes' motivation in adopting the creation doctrine. Many cite God's omnipotence, arguing that it requires that there be no constraints on God and hence that God freely creates even the eternal truths. (See, for example, Curley, 1984; Broughton, 1987; Alanen, 1991.๑) But God's simplicity has also been invoked to explain why Descartes espouses the creation doctrine, as has his physics. ${ }^{7}$ None of these reasons are dispositive. Leibniz, for example, rejected the theological grounds; according to him, Descartes' creation doctrine unknowingly destroys "all the love of God and all his glory" (Leibniz, 1686, p. 304). And as Malebranche argues in his Search After Truth, physics and indeed all science would seem to be impossible if Descartes' creation doctrine were true; scientific inquiry is possible, Malebranche thinks, only if the eternal

5 In a letter to Mersenne written on 6 May 1630, Descartes writes that "the existence of God is the first and most eternal of all possible truths and the one from which alone all others proceed" (CSMK III 24; AT I 150), suggesting thereby (what one might in any case have suspected given that, according to Descartes, God is the only necessary being) God does not freely create the eternal truths about God. Pessin (2006) argues that Descartes holds "at least philosophically speaking" that all eternal truths, including those concerning God, are created.

6 Walski also traces the doctrine to God's nature, arguing that in Descartes we find a very untraditional conception of God, "a God who, while he has the traditional divine attributes, has them in a way conceived so uniquely that from them it follows that he created the eternal truths" (Walski, 2003, p. 23).

7 Broughton (1987) and Kaufman (2003) argue that God's simplicity, the fact that (according to Descartes) in God willing, understanding, and creating are one, provides Descartes with a reason for espousing the doctrine. Osler (1985) suggests that divine omnipotence is the ground for thinking that God freely creates the eternal truths, and divine simplicity the ground for thinking that they are nonetheless eternal and immutable. Kenny (1970) claims that the creation doctrine is required as a foundation for Descartes' physics. There is, however, a serious tension between the creation doctrine and Descartes' physics insofar as Descartes thinks that he can derive the basic laws of motion from God's essence. If God freely creates those laws it would seem to follow that they are not deducible from consideration of God's essence (see Nadler, 1987). 
truths are independent of God's will—though not of his understanding. Of course, none of this shows that these were not Descartes' reasons, even if not very good ones. ${ }^{8}$ Nevertheless, one would like to do better. I aim to show that we can, first, by coming to clarity about the role the creation doctrine was to play in Descartes' new science, and in light of that, by explicating what exactly the doctrine is. ${ }^{9}$

I further hope to make it clear that this doctrine is not merely of scholastic or academic interest, that it constitutes an important moment in our ongoing understanding of the nature of mathematical truth in particular. Descartes, I will argue, needs to give an account of mathematical truth as contrasted with logical truth precisely because he has seen that mathematical truths are necessary but not logically necessary. By contrast with Hume, Descartes does not think that the truths of mathematics are analytic in Kant's sense. They are, in Kant's terminology, synthetic a priori. Understanding why the founder of analytic geometry held this characteristically modern view of the truths of mathematics is an important moment in our overall understanding of the rise of modern mathematics and mathematical science.

\section{The context}

In the spring of 1630 , Descartes discussed the creation doctrine in three letters to Mersenne. In the first, which introduces the idea, Descartes reports that he has made some new discoveries that have led him to abandon his earlier work, including the Rules for the Direction of the Mind, which Descartes had ceased to work on in 1628, and start fresh on a new and larger project. In particular, he reports, "I think that I have found how to prove metaphysical truths in a manner which is more evident than the proofs of geometry" (CSMK III 22; AT I 144). Seven months later, in a letter to Mersenne of 25 November 1630, Descartes is more specific: he has found a proof for the existence of God "which makes me know that God exists with more certainty than I know the truth of any proposition of geometry" (CSMK III 29; AT I 182). His plan is to write a

8 As will be explained in more detail below, we here need to distinguish between what Descartes says are his reasons and what actually are his reasons. As many have argued, if his reasons are as he says, grounded in the nature of God, then the view seems deeply incoherent.

9 My focus here can be only on the creation doctrine itself; I leave to another occasion the task of assessing the merits of the view developed here in relation to other accounts presented in the literature. 
treatise on optics to test "whether I am capable of explaining my conceptions and convincing others of truths of which I have convinced myself," and if successful to "complete a little treatise on Metaphysics [...] in which I set out principally to prove the existence of God and of our souls when they are separate from the body, from which their immortality follows" (CSMK III 29; AT I 182). Descartes' treatise on optics, together with his Geometry and a treatise on meteorology, appeared as appendices to his Discourse on Method in 1637. The Meditations on First Philosophy "in which [according to the subtitle] are demonstrated the existence of God and the distinction between the human soul and the body" was published four years later, in 1641.

By 1630, Descartes had set aside, unfinished, the Rules for the Direction of the Mind and was embarked on what would become the Discourse and the Meditations, both of which, we are told, employ a new and very powerful method, one that enables a proof of the existence of God that is even more certain than demonstrations in geometry. In order to understand this new method we need to think first about the old, the method of the Rules, and in particular, about the role that images and the imagination play in it. Descartes writes in Rule Fourteen:

Even if the intellect attends solely and precisely to what the word denotes, the imagination nonetheless ought to form a real idea of the thing, so that the intellect, when required, can be directed towards the other features of the thing which are not conveyed by the term in question, and so that it may never injudiciously take these features to be excluded. (CSM I 61; AT $\mathrm{X} 445)$

Using the example of extension to illustrate his point, Descartes argues, first, that if one reflects on the notion of extension using only one's intellect and logic, one might well come to think that there can be extension in the absence of any body, "that it is not self-contradictory for extension per se to exist all on its own even if everything extended in the universe were annihilated" (CSM I 59; AT X 443). Nonetheless, Descartes continues, this would be "an incorrect judgment of the intellect alone" (CSM I 59; AT X 443). Because we cannot imagine extension except as the extension of some body, though we can think extension without body, we are able to recognize the necessity of the fact that all extension is of a body. Although the notion of extension does not include the notion of a body, nor the notion of a body that of extension (which is why it is not by logic and reason alone that we are able to discover their necessary relation), nevertheless the two notions are necessarily related one to the other, 
as is shown by our inability to imagine the one without the other. ${ }^{10}$

Because the notion of extension does not contain the notion of a body (nor the notion of a body that of extension), one cannot by reasoning and logic discover that all extension is of a body. It is not logically necessary that all extension is of a body. And yet, Descartes holds, it is necessary that all extension is of a body, and discoverably so. The way we discover this necessary but non-logical truth, according to the account in the Rules, is by trying to imagine extension without any body, by trying to form what Descartes describes as a "real idea" of it. What we discover when we do form a real idea of extension, when we not only think of extension but imagine it, is that extension is and must be of a body. It is in just this way that the intellect is directed by the imagination "towards the other features of the thing which are not conveyed by the term in question, and [...] may never injudiciously take those features to be excluded" (CSM I 61; AT X 445). What is conveyed already by the term is what can be discovered independent of the imagination and is logically necessary; what requires also the imagination to be discovered is "other features of the thing" that are necessarily true of it despite not being contained already in the idea of it.

Descartes retained throughout his life the view that there is no extension without body. He did not, after 1630, maintain that we know this by employing our powers of imagination. That there is no extension without a body comes instead to have the status of an eternal truth that God creates and implants in us. We read, for example, in a letter to Arnauld, 29 July 1648:

I would not dare say that God cannot make a mountain without a valley, or bring it about that 1 and 2 are not 3 . I merely say that he has given me such a mind that I cannot conceive a mountain without a valley, or a sum of 1 and 2 which is not 3; such things involve a contradiction in my conception. I think the same should be said of a space which is wholly empty, or of an extended piece of nothing [...] for wherever extension is, there, of necessity, is body also. (CSMK III 358-359; AT V 224)

10 The distinction between what is logically necessary and what is necessary but not logically necessary is in essence this. What is logically necessary is what is required by the law of noncontradiction, that not ( $p$ and not- $p$ ). One and the same thing cannot both be the case and not the case. What is necessary but not logically necessary is what is required by virtue of the sorts of things involved. Given what it is to be square and what it is to be round, nothing could at once be both. (Compare what it is to be square and what it is to be blue; in this case it is perfectly possible for a thing to be both.) That something might be at once square and round is impossible, though not logically impossible, not impossible in the way it is impossible for something to be at once square and not square. 
Although at first Descartes thought that one might know that extension is necessarily of a body by virtue of the fact that one cannot imagine or form a real idea of extension independent of any body, after 1630 he holds that it is by the intellect alone, reflecting on ideas that are implanted in us by God that we are able to discover such a necessary but not logically necessary truth. And this is especially important in this context because, as Descartes explains in a letter to Mersenne of 27 May 1638, some questions "like the questions of the existence of God and of the human soul" are "beyond the capacity of our imagination" but can be successfully addressed by the intellect: "our intellect can reach the truth of the matter" on such questions (CSMK III 103; AT II 138). Indeed, as Descartes remarks in a letter to Mersenne a year and a half later (13 November 1639), "the imagination $[\ldots]$ is more of a hindrance than a help in metaphysical speculation" (CSMK III 141; AT II 622). As he further explains in the fifth Meditation, we would much more easily acknowledge God were we not besieged by images of things (CSM II 47; AT VII 69). Not only is the imagination unequal to the task of discovering at least some of the necessary but not logically necessary truths, it can be a positive hindrance in the discovery of such truths.

Already in November of 1630 Descartes had reported to Mersenne that he had a proof for the existence of God that was more certain than any demonstration in geometry, and that proof was, presumably, that which we find in the Meditations, either the third Meditation proof or the fifth Meditation proof. Such a proof does not rely on images but depends instead on ideas that are, according to Descartes, implanted in us by God. The proof is discoverable by the intellect acting alone, independent of the imagination and independent of the body on which the imagination appears to depend. (Descartes suggests in the sixth Meditation that imagination seems to involve a kind of turning "towards the body" (CSM II 51; AT VII 73). See also Descartes' letter to Gibieuf, 19 January 1942 (CSMK III 203; AT III 479).) The creation doctrine seems, then, to have been motivated by limitations of the method of inquiry that Descartes sets out in the Rules, by the fact that that method can be of no assistance in establishing such a necessary but not logically necessary truth as, for instance, that God exists. The role that is played in Descartes' early work by images and the exercise of the imagination in the discovery of necessary but not logically necessary truths is now to be played by the God-created eternal truths. 


\section{Necessary but not logically necessary}

If, as I have suggested, the creation doctrine is motivated by limitations in the method of the Rules and in particular by problems with Descartes' appeal to the imagination, then it would seem that the eternal truths should be one and all necessary but not logically necessary. According to the Rules, what is logically necessary can be discovered by reason alone unaided by the imagination; only what is not logically necessary but necessary nonetheless requires the assistance of the imagination. We will see that all Descartes' examples of eternal truths that are created by God reinforce this point.

Consider, first, the truth regarding extension that Descartes first thinks is known with the help of the imagination and later takes to be a God-created eternal truth. We know that this is not logically necessary because, as Descartes explains in his letter to Gibieuf, 19 January 1642, one can mentally abstract extension from shape and body, that is, "consider shape without thinking of the substance or extension whose shape it is"; "one can think of the one without paying attention to the other" (CSMK III 202; AT III 475). Because one can coherently consider one of these notions without the others, can coherently mentally abstract one from the other, it is possible to know that none are contained in any of the others - though if they were, one could, by logic alone, discover this. But this is nonetheless an abstraction, not what Descartes describes as a "complete idea," which is an idea that can be conceived "entirely on its own" (CSMK III 202; AT III 475). As Descartes goes on in that same letter, the same is true of a mountain and a valley: although "by abstraction we can obtain the idea of a mountain, or of an upward slope, without considering that the same slope can be travelled downhill", "the ideas of these things cannot be complete when we consider them apart” (CSMK III 202; AT III 476-477). We can consider a mountain without thereby considering a valley as well, and can consider a valley without also considering a mountain. There is no logically necessary relation between being a mountain and being a valley. But there is a necessary relationship nonetheless insofar as a complete idea of a mountain involves that of a valley. We will return to the question what it is to have a complete idea.

In the third of the three letters Descartes writes to Mersenne in 1630 regarding the creation doctrine, he gives as an example of an eternal truth freely created by God that all radii of a circle are equal. This of course follows immediately, and by logic alone, from the definition of a circle, that all points on the circumference are equidistant to a center. But this definition is not logically necessary as is 
shown by the fact that it is not logically necessary that the radii of a circle are all equal in length. To be a radius of a circle is to be a straight line from the center of a circle to a point on its circumference. There is nothing in the very idea of a radius to suggest that any two radii of a circle are (and must be) equal in length. As the point can be put, although it follows from something's being a circle, circle's being what they are, that all its radii are equal in length, it is no part of being a circle that this is true. There could, as a matter of logical possibility, be a circle with radii unequal in length in a way there could not be a circle that was nonetheless not a circle (which would, of course, be a logical contradiction). God, Descartes suggests, could have made it to be the case that circles are very different from circles as we know them in mathematics, that the definition of a circle could have been different, without circles ceasing to be circles. The truth that all radii of a circle are equal is necessary without being logically necessary.

In the first Replies Descartes discusses another example, discussed also in the fifth Meditation along with the mountain/valley example, that of the three angles of a triangle, that they sum to two right angles, which is of course demonstrably true in Euclidean geometry. And here he does say that its three angles being equal to two right angles is "contained in the idea of a triangle" (CSM II 84; AT VII 117). But if that were true then one could know by logic alone that the sum of the angles of a triangle equals two right angles because it would in that case be a logical contradiction to deny it. Descartes immediately goes on explicitly to deny that there is any logical contradiction here:

Even if I can understand what a triangle is if I abstract from the fact that its three angles are equal to two right angles, I cannot deny that this property applies to the triangle by a clear and distinct intellectual operation-that is, while at the same time understanding what I mean by my denial. (CSM II 84; AT VII 117-8)

Descartes makes three claims here. First, one can understand what a triangle is independent of the question of what its angles sum to; the notion of a triangle does not itself contain the idea that the sum-angle property (i.e., the property of having its angles sum to two right angles) holds. Second, there is a "clear and distinct intellectual operation" the performance of which makes manifest that the sum-angle property is a property of triangles - though just what operation this is remains obscure. And finally, Descartes claims that one can understand what it means to deny that triangles have the sum-angle property, which is to say it is not a logical contradiction to say that triangles do not have the sum-angle property. That triangles have this property is necessary but not logically necessary. One can 
coherently think of a triangle without thinking of such a property as belonging to it. As we are told in the sixth Replies, God did not "will that the three angles of a triangle should be equal to two right angles because he recognized that it could not be otherwise [...] On the contrary, [...] it is because he willed that the three angles of a triangle should necessarily equal two right angles that this is true and cannot be otherwise" (CSM II 291; AT VII 432).Consider, finally, the truth that one plus two equals three. Is this necessary without being logically necessary? Kant would say so on grounds that the concept of the sum of one and two, although it contains the idea that there is a number that is the sum, does not as such contain the idea of the number three. (See Kant's discussion of the sum of seven and five in the B Introduction of the Critique of Pure Reason.) No amount of analysis of the concept sum of one and two will yield the notion of three despite the fact that it is a necessary truth that the sum of one and two is three. It is necessary without being logically necessary; in Kant's terminology, it is synthetic a priori rather than analytic. Descartes similarly says that there is a "contradiction in my conception" to suppose that a sum of one and two not be three, though he "would not dare to say that God cannot [...] bring it about that 1 and 2 are not 3" (CSMK III 358-359; AT V 224).

Perhaps it will be objected that there is a logical contradiction in denying that one plus two is three on the grounds that if you have one thing and add two more things then you have three things, whether or not anyone knows this. And certainly it is true that if you have one thing and add two more then you have three things. What this is not is a truth of mathematics. One can put together as many collections of one thing and two things as one likes, one will not thereby establish the mathematical truth that one plus two equals three. To establish this truth of mathematics requires, as in the case of the triangle, a clear and distinct intellectual operation, an act of recognition that the number that is the sum of one and two is the very same number as the number three. Because one can fully grasp what it is to be the sum of one and two in abstraction from the notion of the number three, it is not by logic alone that one knows the mathematical truth that one plus two equals three. This mathematical truth is necessary but not logically necessary, just as Kant would later argue. 


\section{The status of logical truths}

As already noted, it is often thought that Descartes' creation doctrine applies to logically necessary truths as well as to the necessary but not logically necessary truths of mathematics and metaphysics. This is furthermore thought to follow from God's omnipotence. Certainly it is true that if the truths of logic are anything at all, and if all that is depends on the will of God, then the truths of logic depend on the will of God. But although it does seem to be true according to Descartes that all that is depends on the will of God, it is much less clear that the truths of logic are something (and hence in need of being created), that they exist in any sense that would include them in the class of things dependent on God's will. It rather seems to be the case, we will see, that what is logically impossible simply is not, that in no sense does it or could it exist. Indeed, this is a corollary of the fact that in a purely logical step of inference one does not really take a step of reasoning at all but cognitively stays in just the same place, affirming only what had been, perhaps only implicitly, affirmed already in one's starting point.

The passage most often cited as showing that logical truths are among the Godcreated eternal truths is in a letter to Mesland, 2 May 1644:

I turn to the difficulty of conceiving how God would have been acting freely and indifferently if he had made it false that the three angles of a triangle were equal to two right angles, or in general that contradictories cannot be true together. It is easy to dispel this difficulty by considering that the power of God cannot have any limits, and that our mind is finite and so created as to be able to conceive as possible things which God has wished in fact to be possible but not to be able to conceive as possible things which God could have made possible but which he has nonetheless wished to make impossible. The first consideration shows us that God cannot have been determined to make it true that contradictories cannot be true together, and therefore that he could have done the opposite. The second consideration assures us that even if this be true, we should not try to comprehend it since our nature is incapable of doing so. (CSMK III 235; AT IV 118; emphasis added.)

Descartes clearly says in this letter that God is not determined to hold that contradictories cannot be true together, and if by 'contradictories' he means logical contradictories - such as that this $S$ is $\mathrm{P}$ and that this (same) $\mathrm{S}$ is in addition not $\mathrm{P}$, or more generally, that $p$ and not $-p$ — then the creation doctrine 
applies not only to truths of mathematics and metaphysics (which, we are supposing, are necessary but not logically necessary) but also to truths of logic. If, however, by 'contradictories' he means only conceptual or metaphysical, but not logical, contradictories such as being square and being round, say, or being extended but not a body, then the creation doctrine is limited to non-logical necessary truths.

Descartes nowhere says that God could make it the case that some one thing is both $\mathrm{F}$ and not $\mathrm{F}$ for some property $\mathrm{F}$, or that it could have been true that both $p$ and not- $p$. And all his examples are of conceptual or metaphysical impossibilities as such impossibility contrasts with logical impossibility. They give one no grounds for thinking that the creation doctrine applies to logically necessary truths as well as to truths that are necessary but not logically necessary. Positive grounds for thinking that Descartes does not apply the doctrine to what is logically true is that he holds that it is no constraint or limitation on God that God cannot do what it is logically impossible to do. Descartes writes to More on 5 February 1649: "we do not take it as a mark of impotence when someone cannot do something which we do not understand to be possible." For example, "we do not $[\ldots]$ perceive it to be possible for what is done to be undone-on the contrary, we perceive it to be altogether impossible, and so it is no defect of power in God not to do it" (CSM II 363; AT V 273). It is logically impossible to make to have not been done what has been done because that is as much as to say that an object can both have and lack one and the same property, that it both is and is not, which simply cannot be. God's inability to do what is logically, or absolutely, impossible is not, then, an inability; it is not a mark of any sort of limitation or impotence.

In his Second Replies, Descartes further explores the notion of possibility. One sense of 'possible', he thinks, is "what everyone commonly means, namely 'whatever does not conflict with our human concepts'". And while we might think we can imagine another kind of possibility "which relates to the object itself [...] unless this matches the first sort of possibility it can never be known by the human intellect" (CSM II 107; AT VII 150-151). Thus,

all self-contradictoriness or impossibility resides solely in our thought, when we make the mistake of joining together mutually inconsistent ideas; it cannot occur in anything which is outside the intellect. For the very fact that something exists outside the intellect shows that it is not self-contradictory but possible. (CSM II 108; AT VII 152) 
Descartes claims in this passage that the only notion of impossibility that is intelligible is that of the material incompatibility of concepts, "mutually inconsistent ideas". But if so, then, what is logically impossible is nothing at all. It simply is not, and hence, again, it is no limitation on the power of God not to be able to do what it is logically impossible to do. (This was also the scholastic view, the view of, for instance, Aquinas: what is logically impossible cannot be done and thus it is wrong to say that God cannot do what is logically impossible as if God were in some way limited or constrained by logic. ${ }^{11}$ )

The case of contradictions in one's conceptions of things is different. Here the contradiction is not logical but instead conceptual or metaphysical. And it is grounded, Descartes thinks after 1630, in the true and immutable natures that God has created. Because these are not logically necessary but depend on God's free decree there is a sense in which they could be otherwise. Thus Descartes writes to Mersenne on 27 May 1630 that "it is certain that he [God] is the author of the essence of created things no less than of their existence; and this essence is nothing other than the eternal truths [...] You ask also what necessitated God to create these truths; and I reply that he was free to make it not true that all the radii of the circle are equal-just as free as he was not to create the world" (CSMK III 25; AT I 152). In a letter written to Mersenne eight years later (again on May 27), we read that "even those truths which are called eternal—as that 'the whole is greater than its part'-would not be truths if God had not so established" (CSMK III 103; AT II 141). Further textual evidence is provided in Descartes' letter to Gibieuf of 19 January 1642. Descartes writes: "we cannot have any knowledge of things except by the ideas we conceive of them; and consequently [...] we must not judge of them except in accordance with these ideas, and we must even think that whatever conflicts with these ideas is absolutely impossible and involves a contradiction" (CSMK III 202; AT III 476). Then, in a letter to More, 15 February 1649, Descartes writes that "I boldly assert that God can do everything that I perceive to be possible but I am not so bold as to assert the converse, namely that he cannot do what conflicts with my conception of things-I merely say it involves a contradiction" (CSMK III 363; AT V 272). In both cases Descartes is clearly talking about conceptual rather than logical contradiction, and yet he describes it as "absolutely impossible" or simply as involving a contradiction. Again, there is an important sense in which there is no logical contradiction according to Descartes.

11 See, for example, Aquinas' Summa Theologica, Q. 25, Art. 3. 
Descartes does not claim in the creation doctrine that God can do even what it is logically impossible to do. The claim is rather that God could have made the essences and necessary (but not logically necessary) relations of mathematical and metaphysical entities different from what they are. When Descartes talks of impossibility, he does not mean logical impossibility, which, he thinks, is nothing at all, but instead what is impossible given our conceptions of things, given, that is, the God-created essences and God-created relations among things. As Descartes remarks in the Second Replies, all impossibility is what I am here calling conceptual impossibility: "All self-contradictoriness or impossibility resides solely in our thought, when we make the mistake of joining together mutually inconsistent ideas" (CSM II 108; AT VII 152).

\section{Creating the eternal truths}

After 1630 Descartes holds that God creates the eternal truths of mathematics and metaphysics. Such truths, I have argued, are necessary without being logically necessary. And I have further argued that what is logically necessary needs no creative act because it, like what is logically impossible, is nothing at all. Interestingly, Descartes indicates that even God's existence is not logically necessary insofar as both the third Meditation proof for the existence of God and the fifth Meditation proof rely on necessary but non-logical truths. The third begins from one's own contingent existence as a finite being with doubts and takes as a crucial premise the necessary but non-logical truth that the cause of an idea must have at least as much formal reality as the idea has objective reality; it is this premise that enables one to infer that only God could be the cause of one's idea of God and hence must exist. But, again, this is not a logical truth: there is nothing about objective and formal reality in the very idea of a cause of an idea. Nevertheless, Descartes claims, "it is manifest by the natural light that there must be at least as much <reality> in the efficient and total cause as in the effect of that cause," from which it follows, he thinks, that the cause of an idea must have as much formal reality as the idea has objective reality (CSM II 28; AT VII 40).

The third Meditation proof of God's existence begins from one's own existence as a finite being with questions and doubts. The fifth Meditation proof begins directly from the concept of God: because God has, must have, all perfections, and existence is a perfection, God must then exist. This proof may seem to be analytic, merely a matter of unpacking, making explicit, what is contained 
already in the concept God. The text of the fifth Meditation suggests otherwise. Descartes writes:

Since I have been accustomed to distinguish between existence and essence in everything else, I find it easy to persuade myself that existence can also be separated from the essence of God, and hence that God can be thought of as not existing. But when I concentrate more carefully, it is quite evident that existence can no more be separated from the essence of God than the fact that its three angles equal two right angles can be separated from the essence of a triangle, or that the idea of a mountain can be separated from the idea of a valley. Hence it is just as much a contradiction to think of God (that is, a supremely perfect being) lacking existence (that is, lacking a perfection) as it is to think of a mountain without a valley. (CSM II 46; AT VII 66)

Existence is not contained in the essence of God any more than it is contained in any other essence. It is not logically necessary that God exists. Still, Descartes argues, one cannot form a real or complete idea of God (to use terminology he employs elsewhere) without thinking also that God exists. Just as one cannot form a real or complete idea of a mountain without a valley or of a triangle without the angle-sum property so one cannot form a real or complete idea of God without existence. That God exists is necessary but not logically necessary. According to Descartes, then, God created us with the capacity to discover by reason alone that God exists and did so by implanting in us ideas on the basis of which to infer that God exists. Only because we are able to discover God-created necessary but not logically necessary truths that are innate in us can we come to know of God's existence.

According to Descartes, logically necessary truths have no content just because they are logically necessary. Their negations are absolutely impossible, nothing at all, and hence they are likewise nothing. Logically necessary truths do not, then, need to be created. Contingent truths also do not need to be created, though for a very different reason. There is no need for God to create any contingent truths (in a separate act of creation) because having created the world, that is, all the bodies and minds there are with all their various properties and relations, God thereby makes it true (as a matter of fact) that this and that are thus and so. In order to make it true that I exist, for example, it is enough that I am brought into existence. To create objects with their properties and relations just is to create thereby the relevant truths about them. But that takes care only of contingent truth. It is not by creating the bodies and minds there are, together with their properties and relations, that one creates the necessary truths. Suppose, for 
example, that God created the world in such a way that wherever there was extension there was also body, that nowhere was there extension that was not the extension of a body. That would not be sufficient to establish that all extension must be the extension of some body but only that, as a matter of fact, all extension is the extension of a body. Because they are necessary rather than contingent, and yet not logically necessary, the eternal truths require a separate act of creation over and above the creation of the world, bodies and minds together with their properties and relations.

But how exactly is an eternal truth to be created? In particular, how might such a truth be created if not by creating that about which it is a truth? And if one does create a necessary truth by creating the thing about which it is a truth, how does one, even an omnipotent being such as God, create something to have the relevant property necessarily? It is easy to see that this approach to the question of how the eternal truths are created, modeled on the creation of contingent truths, cannot be right. In the first place, we know that there are necessary truths about, say, triangles (and other mathematical and metaphysical entities) that hold independent of the existence of any triangles (or other mathematical or metaphysical entities). "Even if perhaps no such figure exists, or has ever existed, anywhere outside my thought, there is still a determinate nature, or essence, or form of the triangle which is immutable and eternal, and not invented by me or dependent on my mind" (CSM II 45; AT VII 64). There are necessary truths about things independent of the existence of those things. It furthermore cannot be right that God creates the eternal truths simply by creating our minds to have, as a matter of fact, a propensity to think that there are such necessary truths. Insofar as God is not a deceiver, what we perceive clearly and distinctly to be true must actually be true; it cannot merely be something we have, as a matter of fact, been caused to think.

Although the creation of the contingent truths is effected through the creation of the things of which they are true together with the relevant properties and relations, necessary truths cannot be created in the same way. So how are they created? To answer that question we need first to know what it is that is created in creating the eternal truths. Descartes' answer is clear: laws, more exactly, laws of the mind, that is, rules governing acts of inference. As we read already in the letter to Mersenne in which Descartes first announces the creation doctrine,

It is God who has laid down these laws in nature just as a king lays down laws in his kingdom. There is no single one that we cannot grasp if our mind turns to consider it. They are all †inborn in our minds $\dagger$ just as a king would 
imprint his laws in the hearts of all his subjects if he had enough power to do so. (CSMK III 23; AT I 145)

In the letter of 27 May 1630, in response to Mersenne's asking what God did in order to produce the eternal truths, Descartes explains that " $f$ from all eternity he willed and understood them to be, and by that very fact he created them $\dagger$. Or, if you reserve the word $\dagger$ created $\dagger$ for the existence of things, then he †established them and made them $\dagger$ " (CSMK III 25; AT I 152-153). That the eternal truths are not themselves things, objects, and are not created through the creation of things, (whether minds or bodies) is indicated also in Descartes' fifth Replies. He writes in response to Gassendi's concerns about the mathematical essences of things:

you say that you think it is 'very hard' to propose that there is anything immutable and eternal apart from God. You would be right to think this if I was talking about existing things or if I was proposing something as immutable in the sense that its immutability was independent of God [...] I do not think that the essences of things, and the mathematical truths we can know concerning them, are independent of God. Nevertheless I do think that they are immutable and eternal, since the will and decree of God willed and decreed that they should be so. (CSM II 261; AT VII 380)

The creation of the eternal truths is not a matter of creating things, bodies and minds. The eternal truths are instead laws that are decreed. The point is reinforced in the sixth Replies in which Descartes compares God's creation of "truths, both mathematical and metaphysical" to a king's laying down the law of the land. God is the efficient cause of the eternal truths "in the sense that a king may be called the efficient case of a law, although the law itself is not a thing which has physical existence, but is merely what they call a 'moral entity". "The eternal truths $[. .$.$] depend on God alone, who, as the supreme legislator,$ has ordained them from eternity" (CSM II 294; AT VII 436). Again, these are not laws of things, as we know given that they are binding even were there no triangles or material bodies at all. They are laws of the mind, of inference, of the passage from one thought to another.

To say that As are necessarily $B$, though being $B$ is not contained already in the very idea of $A$, is to say, at least, that one can infer from something's being $A$ that it is $\mathrm{B}$. And by contrast with a law of logic, that is, with a case in which being $\mathrm{B}$ is contained already in the concept of A, such a license really is a license, something that permits one to do something that one could not otherwise do. It governs 
the passage from the judgment that a thing is $\mathrm{A}$ to the judgment that it is $\mathrm{B}$, where this is not merely a matter of making explicit something that is contained already in the judgment that the thing is A but is ampliative, a real extension of our knowledge. What God creates in creating the eternal truths are rules of inference, not logical or merely formal rules (which we have seen need no act of creation because they are not inference licenses at all but only a means of making things explicit), but material rules, rules that govern the passage from one claim to a different claim, one that is entailed by the first but not contained already in it. And much as creating the empirical world is sufficient for the creation of all the contingent truths, so creating such material rules of inference as there are is sufficient for the creation of all the necessary but non-logical truths, what Descartes calls the eternal truths. The mere fact that being $A$ entails being $B$, that there is an inference license to that effect, is sufficient to explain the (non-logical) truth that all As are and must be B. And now we can understand what it is to have a complete, or real, idea. Such an idea comprises not only what is the case given the concept in question (say, that of a mountain), but also what follows, namely, that there is a valley as well.

To create the eternal truths of mathematics and metaphysics it is sufficient to decree certain laws of thought, rules permitting one to infer something not contained in what one already knows and extending thereby one's knowledge. In the case of a triangle, for example, "it is necessary that I attribute to it the properties which license the inference that its three angles equal no more than two right angles" (CSM II 47; AT VII 67-68). Although the conclusion is not contained already in one's starting point, nonetheless everything that is needed in order to draw the conclusion is available. It is the inference, the mental act of reasoning that Descartes describes in the first Replies as a "clear and distinct intellectual operation," that enables an extension of one's knowledge. And Descartes is quite explicit about this, even in the Rules. Deduction as described in Rule Three is "the inference of something as following necessarily from some other propositions which are known with certainty" (CSM I 15; AT X 369). It is an act of mind that extends one's knowledge. And much as one cannot see or know what is not so, so one cannot deduce what is not so-although of course one can seem to. "Deduction [...] is not something a man can perform wrongly" (CSM I 14; AT X 368).

In the second Replies, Descartes distinguishes two methods of demonstration, by analysis and by synthesis. Analysis, "which is the best and truest method of instruction” (CSM II 111; AT VII 156), 
shows the true way by means of which the thing in question was discovered methodically and as it were a priori, so that if a reader is willing to follow it and give sufficient attention to all points, he will make the thing his own and understand it just as perfectly as if he had discovered it for himself. But this method contains nothing to compel belief in an argumentative or inattentive reader; for if he fails to attend even to the smallest point, he will not see the necessity of the conclusion. (CSM II 110; AT VII 155-156)

Analysis, on Descartes' account, is ampliative; it reveals new things and does so, as Descartes thinks of it after 1630, by utilizing the inference licenses that are laid down by God and underwrite the eternal truths of mathematics and metaphysics. But once having discovered some chain of reasoning to such a truth it is possible then to formalize the reasoning in such a way that each step of inference is governed not by a rule of material inference but instead by a rule of formal inference, a law of logic. Where there had been a step governed by a rule to the effect that, say, being $A$ entails being $B$ - a rule that licenses a move from the fact that some object is $\mathrm{A}$ to the conclusion that it is $\mathrm{B}$-now there is an added premises stating that all $\mathrm{A}$ is $\mathrm{B}$. Where before one was able to infer, given that some object is A, that it is B, now one's premises contain already this information. All that one's inference (now only so-called) does is to make that information explicit. This strictly formal, strictly logical method is what Descartes calls synthesis: "it demonstrates the conclusion clearly and employs a long series of definitions, postulates, axioms, theorems and problems, so that if anyone denies one of the conclusions it can be shown at once that it is contained in what has gone before, and hence the reader, however argumentative or stubborn he may be, is compelled to given his assent" (CSM II 111; AT VII 156). In the formal proof, unlike the original, materially valid one, the conclusion is contained already in one's premises; all the proof does is make that explicit. But because it only makes explicit what was implicit already in one's premises, such a formal proof, although it compels assent, is actually more liable to error than the original, materially valid proof. As Descartes explains in Rule Ten of the Rules, in formally or logically valid inferences "the conclusions follow with such irresistible necessity that if our reason relies on them, even though it takes, as it were, a rest from considering a particular inference clearly and attentively, it can nevertheless draw a conclusion which is certain simply in virtue of the form" (CSM I 36; AT X 405-406). Not only can we learn nothing new from a logically valid inference, because it is valid in virtue of form-because one does not need to attend to the content, what is actually being asserted-formal reasoning can easily lead one astray. One thinks that one's conclusion is true 
because it follows logically from one's (apparently true) premises but perhaps it is instead the case that one or more of one's premises are false, something that one is liable to notice only if one is actually thinking about what those premises mean and what follows if they are true. Thus, Descartes concludes, "ordinary dialectic [that is, pure, formal logic] is of no use whatever to those who wish to investigate the truth of things" (CSM I 37; AT X 406).

\section{Conclusion}

Descartes' creation doctrine, his claim that God freely creates the eternal truths of mathematics and metaphysics, is almost universally regarded as an extremely bizarre and unfortunate idea. I have tried to show that it is not. And we see that it is not when we consider the fundamental changes, right around the time Descartes first espouses the doctrine, in Descartes' view of how inquiry in mathematics and metaphysics works. Once Descartes came to see that images are not needed in mathematics and first philosophy, he needed some other way to explain how we achieve knowledge of the necessary but not logically necessary truths of mathematics and metaphysics, how we achieve such knowledge using only the pure intellect. Given his conception of intuition and deduction in the Rules, and of clear and distinct perceptions in later works, it would suffice if God were to create, that is, decree, the non-logical inference rules that govern our thinking, at least when we are engaged in the analytic method of demonstration. And this, I have argued, is just what Descartes did come to think. God is the author of the necessary unities of conceptual contents that are exhibited in non-logical rules of inference concerning what entails and is entailed by what. And we come to grasp such rules through our clear and distinct grasp of the relevant concepts; we come to see what follows in light of things we already know. And because these inferences are not strictly logical, not merely a matter of making explicit something that is implicitly contained already in our starting points, to make such an inference is to discover something new, something enabled by one's starting point but not contained already in it. It was Descartes' transformed practice, his discovery that images are not needed in mathematics and metaphysics, that directly explains why Descartes came to think that God freely creates the eternal truths of mathematics and metaphysics, and also thereby what it is to think that. 


\section{References}

Alanen, L. (1988), 'Descartes, omnipotence, and kinds of modality,' in P. H. Hare (ed.) Doing Philosophy Historically, Buffalo, NY: Prometheus Books.

(1991), 'Descartes, conceivability and logical modality,' in T. Horowitz \& G. J. Massey (eds.) Thought Experiments in Science and Philosophy, Savage, MD: Rowman and Littlefield.

Aquinas, T. (2006), Summa Theologiae, Questions on God, ed. by B. Leftow \& B. Davies, Cambridge \& New York: Cambridge University Press.

Ariew, R. (2006), 'Descartes, the first Cartesians, and logic,' in Oxford Studies in Early Modern Philosophy, vol. 3, pp. 241-260.

Bennett, J. (1994), “Descartes' theory of modality," Philosophical Review, vol. 103, pp. 639-667. https://doi.org/10.2307/2186100

Bréhier, É. ([1937]1967), “The creation of the eternal truths in Descartes's system," in W. Doney (ed.) Descartes: A Collection of Critical Essays, London \& Basingstoke: Macmillan and Co Ltd. https://doi.org/10.1007/978-1-349-15265-0_9

Broughton, J. (1987), "Necessity and physical laws in Descartes' philosophy," Pacific Philosophical Quarterly, vol. 68, pp. 205-221.

— (2002), Descartes's Method of Doubt, Princeton \& Oxford: Princeton University Press.

Curley, E. M. (1984), 'Descartes on the creation of the eternal truths,' Philosophical Review, vol. 93, no. 4, pp. 569-597. https://doi.org/10.2307/2184828

Descartes, R. (1984), The Philosophical Writings of Descartes, vol. II [CSM II], transl. by J. Cottingham, R. Stoothoff \& D. Murdoch, Cambridge: Cambridge University Press.

(1985), The Philosophical Writings of Descartes, vol. I [CSM I], transl. by J. Cottingham, R. Stoothoff \& D. Murdoch, Cambridge: Cambridge University Press.

(1991), The Philosophical Writings of Descartes, vol. III: The Correspondence [CSMK III], transl. by J. Cottingham, R. Stoothoff, D. Murdoch \& A. Kenny, Cambridge: Cambridge University Press.

Frankfurt, H. (1977), 'Descartes on the creation of the eternal truths,' Philosophical Review, vol. 86, no. 1, pp. 36-57. https://doi.org/10.2307/2184161

Funkenstein, A. ([1975]1991), 'Descartes, eternal truths and the divine omnipotence,' in G. J. D. Moyal (ed.) René Descartes: Critical Assessments, vol. 3, London \& New York: Routledge.

Gaukroger, S. (1992), “Descartes's early doctrine of clear and distinct ideas," Journal of the History of Ideas, vol. 53, no. 4, pp. 585-602.

https://doi.org/10.2307/2709939 
Geach, P. (1973), 'Omnipotence,' Philosophy, vol. 48, pp. 7-20. https://doi.org/10.1017/S0031819100060381

Hacking, I. ([1973]2002), 'Leibniz and Descartes: proof and eternal truths,' in Historical Ontology, Cambridge, MA: Harvard University Press.

Ishiguro, H. (1986), 'The status of necessity and impossibility in Descartes,' in A. Rorty (ed.) Essays on Descartes' Meditations, Berkeley \& Los Angeles: University of California Press.

Kant, I. ([1781/1787]1998), Critique of Pure Reason, transl. by P. Guyer \& A. W. Wood, Cambridge: Cambridge University Press. https://doi.org/10.1017/CBO9780511804649

Kaufman, D. (2002), “Descartes' creation doctrine and modality," Australasian Journal of Philosophy, vol. 80, pp. 24-41. https://doi.org/10.1080/0960878032000160235

_ (2003), 'Divine simplicity and the eternal truths in Descartes,' British Journal for the History of Philosophy, vol. 11, pp. 553-579.

Kenny, A. (1970), 'The Cartesian circle and the eternal truths,' Journal of Philosophy, vol. 67, pp. 685-700. https://doi.org/10.2307/2024588

Leibniz, G. W. ([1686]1956), 'Discourse on metaphysics,' in L. E. Loemker (ed.) Philosophical Papers and Letters, Dordrecht, Boston \& London: D. Reidel.

Malebranche, N. ([1674/5]1980), The Search after Truth, transl. by T. M. Lennon \& P. J. Olscamp, Columbus: Ohio State University Press.

Marion, J.-L. (1992), 'Cartesian metaphysics and the role of simple natures,' in J. Cottingham (ed.) The Cambridge Companion to Descartes, Cambridge: Cambridge University Press. https://doi.org/10.1017/CCOL0521366232.005

Miller, L. G. (1957), 'Descartes, mathematics, and God,' Philosophical Review, vol. 66, pp. 451-465. https://doi.org/10.2307/2182744

Nadler, S. M. (1987), 'Scientific certainty and the creation of the eternal truths: A Problem in Descartes,' Southern Journal of Philosophy, vol. 25, pp. 175-192. https://doi.org/10.1111/j.2041-6962.1987.tb01615.x

Nelson, A. (1993), 'Cartesian actualism in the Leibniz-Arnauld correspondence,' Canadian Journal of Philosophy, vol. 23, pp. 675-94.

https://doi.org/10.1080/00455091.1993.10717341

Nelson, A. \& Cunning, D. (1999), 'Cognition and modality in Descartes,' Acta Philosophica Fennica, vol. 64, pp. 137-153.

Nolan, L. (1997), 'The ontological status of Cartesian natures,' Pacific Philosophical Quarterly, vol. 78, pp. 169-194. https://doi.org/10.1111/1468-0114.00034

Normore, C. (1991), “Descartes's possibilities,” in G. J. D. Moyal (ed.) René Descartes: Critical Assessments, vol. III, London \& New York: Routledge. https://doi.org/10.1007/BF01064011

(1993), 'The necessity in deduction: Cartesian inference and its medieval background,' Synthese, vol. 96, no. 3, pp. 437-454. 
Osler, M. J. (1985), "Eternal truths and the laws of nature: the theological foundations of Descartes' philosophy of nature," Journal of the History of Ideas, vol. 46, no. 3, pp. 349-362. https://doi.org/10.2307/2709472

Pessin, A. (2006), 'Descartes on the divine eternal truths,' Yeditepe' de felsefe, vol. 5, pp. 133-166. https://doi.org/10.1007/s11406-009-9189-1

(2010), 'Divine simplicity and the eternal truths: Descartes and the scholastics,' Philosophia, vol. 38, pp. 69-105.

Rozemond, M. (2008), "Descartes's ontology of the eternal truths," in P. Hoffman, D. Owen \& G. Yaffe (eds.) Contemporary Perspectives on Early Modern Philosophy: Essays in Honor of Vere Chappell, Peterborough, Ontario: Broadview Press.

Schmaltz, T. (1991), "Platonism and Descartes' view of immutable essences," Archiv für Geschichte der Philosophie, vol. 73, pp. 129-170. https://doi.org/10.1515/agph.1991.73.2.129

Van Cleve, J. (1994), 'Descartes and the destruction of the eternal truths,' Ratio, vol. 7, pp. 58-62. https://doi.org/10.1111/j.1467-9329.1994.tb00153.x

Walski, G. (2003), 'The Cartesian God and the eternal truths,' in D. Garber \& S. Nadler (eds.) Oxford Studies in Early Modern Philosophy, vol. I, Oxford: Clarendon Press.

Wilson, M. (1978), Descartes, London, Henley \& Boston: Routledge and Kegan Paul. https://doi.org/10.4324/9780203167670

Danielle Macbeth is T. Wistar Brown Professor of Philosophy at Haverford College in Pennsylvania, USA. She is the author of Frege's Logic (Harvard UP, 2005) and Realizing Reason: A Narrative of Truth and Knowing (Oxford UP, 2014), as well as many essays on a variety of issues in the philosophy of language, the philosophy of mind, the history and philosophy of mathematics, and other topics. She was a Fellow at the Center for Advanced Study in the Behavioral Sciences in Palo Alto in 2002-2003, and has been awarded both an American Council of Learned Societies (ACLS) Burkhardt Fellowship and a Fellowship from the National Endowment for the Humanities (NEH). 